\title{
Mandatory Premarital Genetic Screening For Hereditary Disease In Light Of The Five Objectives Of Islamic Law
}

Abul Fadl Mohsin Ebrahim, Ph.D. (Temple, USA)

School of Religion, Philosophy and Classics, University of KwaZulu-Natal, Durban South Africa

Professor Emeritus Abul Fadl Mohsin Ebrahim
Abul Fadl Mohsin Ebrahim, Ph.D. (Temple, USA)

School of Religion, Philosophy and Classics, University of

KwaZulu-Natal, Durban South

Africa

Professor Emeritus Abul Fadl

Mohsin Ebrahim

P.O. Box 65561, Reservoir Hills.

Durban 4091, South Africa

Telephone: +27797513718

Tele-fax :+312607286
"Running title" - Premarital Genetic Screening and Islamic Law

\section{Abstract}

Background: Premarital genetic screening is a test in which prospective married couples undergo specific tests for genetic, infectious and blood transmitted diseases to prevent any risk of transmitting such diseases to their children. Such a test is important in view of the increasing number of children affected with genetic or blood transmitted diseases. In the Arab countries, for example, in the United Arab Emirates (UAE), Saudi Arabia and the Kingdom of Bahrain, their Ministries of Health have made it mandatory for all prospective married couples to undergo the screening process before getting married. This regulation is precisely because of the high prevalence of hereditary disease like sickle cell disease and to a certain extent Thalassemia that may be associated with the prevalence of consanguineous marriages in such countries. While there is obvious benefit for this particular test, Muslim scholars, however, hold differing views on the issue of the enforcement of this test upon the population. While the paper addresses their concerns, it attempts to try to justify mandatory premarital genetic screening in light of the five objectives of Islamic Law.

Methods: The method employed is restricted to desk-top study (qualitative) relying solely on empirical sources.

Keywords: Premarital genetic screening, autonomy, breach of confidentiality, objectives of Islamic Law, legal maxims and genetic counselling.

Synopsis: Premarital genetic screening is being made mandatory in some Middle Eastern countries in order to prevent the birth of children who would inherit genetic disorders. Concerns have been raised such implementation. While the paper addresses their concerns, it attempts to try to justify mandatory premarital genetic screening in light of the five objectives of Islamic Law.

\section{Introduction}

Generally, diseases that affect humans fall in two categories, namely, acquired or hereditary. An acquired disease is a disease that is not present at birth (congenital), but develops later on in life, for example, tuberculosis, etc. Hereditary diseases, on the other hand, are such diseases that are present in the genetic makeup of a person and could be transmitted from generation to generation (Oman Hereditary Blood Disorder Association. 2015).

Premarital genetic screening is a test carried out on prospective couples who intend to get married. The objective is to test them in order to ascertain whether they are carriers of genetic diseases, which 
could be transmitted to their offspring (Eastern Biotech and Life Sciences. 2014).

It is important to note that many parents are unaware that they are carriers of certain genetic disorders in view of the fact that a carrier of a genetic disorder does not carry any morbidity nor does the disorder manifest in one's physical constitution (i.e., no phenotype). Hence, they would become aware that they are carriers of a particular disorder only after their children are born with that specific genetic disorder. For example, in the United Arab Emirates, Saudi Arabia and Bahrain there had been a high prevalence of hereditary diseases like sickle cell anemia and to a certain extent Thalassemia which resulted from consanguineous marriages. This reality prompted the governments in these countries to make it mandatory for all prospective married couples to undergo premarital genetic testing (Rahman, 2014:105).

\section{Merits Of Premarital Genetic Screening}

In a study conducted in Bahrain (Al-Arrayed, 1999) where consanguineous marriages were prevalent, it revealed that because of mandatory premarital genetic counselling and screening the following positive results were achieved:

- Increase of 'separation before engagement' in 'arranged' marriages.

- Decline of $50 \%$ in incidence of sickle cell disease in neonates.

- Decline in rate of cousin marriages from $45.5 \%$ in the previous generation to $39.4 \%$ in the present generation.

- Increase awareness of negative effects of consanguineous marriages.

Shaykh `Abd al-Rashīd Qāsim (2012) concedes that premarital genetic testing will enable prospective marriage couples who were unaware of the fact that they were both carriers of the same genetic disease to be in a more informed. Hence, they would have the option to either call off the marriage or take precautionary measures not to have children if they nevertheless wish to get married to each other.

\section{Concerns}

In the context of mandatory premarital genetic testing, however, several concerns may be raised and some of them are hereunder discussed:

\section{(a) Violation of autonomy}

Autonomy is defined as a principle of medical ethics, which necessitates one to respect the rights of others so that they could freely make their own choices and decisions (Farlex. The Free Dictionary). Thus, the imposition of mandatory premarital genetic testing by the State compromises the autonomy of the populace and that is considered to be unethical.

\section{(b) Falsification of medical certificates}

According to Albar (1998) when the Arab countries were contemplating making premarital genetic testing mandatory in the latter part of the $1900 \mathrm{~s}$ for their citizens, it was feared that the cost of such a test would be too exorbitant and hence most governments would not be able to fund such a test for their subjects. Moreover, citizens residing in the less affluent Arab countries like for example, in Egypt, Morocco and Syria, would decline the test or evade it on the grounds of poverty. Furthermore, it was argued that if premarital genetic testing were to be imposed as a precondition for the solemnization of marriage then that would inadvertently open the doors for trafficking in false medical certificates. However, today, premarital genetic testing is a gratis routine mandatory procedure for the populace in the affluent Middle Eastern countries.

\section{(c) Breach of confidentiality}

The results of premarital genetic testing ought to be confidential in the sense that a physician or other health professional are expected to hold secret all information relating to a patient, unless the patient gives consent permitting disclosure (thefreedictionary.com). Breach of confidentiality insofar as the results of premarital genetic testing is concerned will inevitably undermine their (especially women) chances to have further marriage proposals (Qāsim, 2012) if they are tested positive as carriers of specific genetic disorders.

\section{(d) Limitation of Premarital Genetic Screening}

It is important to note that due to the cost factor, mandatory premarital genetic testing is limited to two or three genetic diseases common amongst local population. However, having undergone premarital genetic screening, the prospective couples, who find out that they are non-carriers of any of the genetic diseases for which they had been tested for, may have the false notion 
that their offspring would be immune from other forms of genetic disorders (Qāsim, 2012). In order to circumvent this, the State absolves itself from any form of liability so as to indemnity itself from ligation by making the prospective couples sign an indemnity form clearly stipulating for what genetic disease/s they had been tested for.

\section{Dissenting Views}

There are some Muslim scholars who oppose mandatory premarital genetic testing and they substantiate their objections on the basis of the following arguments (Qāsim, 2012):

Firstly, they state that the conditions for contracting nikāh (marriage) have clearly been defined in both the Glorious Qur'an and in the Sunnah (Prophetic Traditions). For example, Muslim women are not allowed to marry non-Muslims (Al-Baqarah, 2:221). Likewise, Muslim men are not allowed to marry two sisters at one and the same time and moreover Muslims in general are cautioned against marrying those who are related to them through blood relationship (Al-Nisā', 4:22-23). Hence, they point out that premarital genetic testing cannot be made a condition for marriage since Prophet Muhammad (upon whom be peace and blessings of God) said: "Every condition that does not exist in the Book of God (Qur'ān) is invalid" (Khan, 1997, (3) Hadith no. 2168:212).

Secondly, while one of the primary objectives of marriage is procreation, women who have passed the age of childbearing may also wish to marry for the sake of companionship and not for procreation. It would therefore be meaningless to impose premarital genetic testing on such prospective elderly couples (Qāsim, 2012).

Thirdly, undergoing premarital genetic testing does not in any way guarantee that the offspring of the prospective couples would be totally safeguarded from genetic disorder. Hence, they are of the view that prospective couples ought to supplicate for pious and healthy offspring just like Prophet Zakariyyā (peace be upon him) did: "Then Zakariyyā prayed unto His Lord and said: "My Lord! Bestow upon me Your bounty, a goodly offspring. Lo! You are the Hearer of prayer" (Qur'ān, Âl 'Imrān, 3:38). In other word, the prospective couples must place their tawakkul (trust) in God Almighty and acknowledge the power of du'à' (sincere supplication).
Fourthly, while they do concede that the Muslim ruler has the prerogative to enforce certain matters as mandatory, they are of the view that that such prerogative should be restricted only to such matters which are in the interest of public welfare (al-mașlahah). However, they do not accept premarital genetic testing to be in the interest of public welfare since its negative consequences far outweigh its benefits (Qāsim, 2012). Thus in the context of mandatory premarital genetic testing, they contend that an individual's autonomy should not be compromised and hence prospective marriage couples should be encouraged to undergo premarital genetic testing and to be educated about its benefits, but at the same time they should be allowed to exercise their autonomy either to undergo the test or not.

\section{PREROGATIVESFORTHEENDORSEMENT OFMANDATORYPREMARITAL}

\section{Genetic Screening}

Islamic Medical Jurisprudence is in essence the science which deals with bioethical issues in the field of healthcare and medicine (Ebrahim 2008:3). Thus in light of Islamic Medical Jurisprudence, mandatory premarital genetic testing can be substantiated based on the following considerations:

\section{(a) Textual Evidence}

The Qur'anic verse: “Obey God and obey His messenger and those in authority amongst you" (Al-Nisā', 4:59) justifies Muslims to uphold the State's imposition of mandatory premarital genetic testing in the interest of a pressing social need, namely, to safeguard its population from inheriting genetic disorders.

(b) Maqāsid al-Sharīah al-Khamsah (the five Objectives of Islamic Law)

Imām Abū Hāmid al-Ghazālī (1904, 258) classified the five overarching objectives (maqāsid) of the Sharīah into the following order:

1. Protection of Faith ((hifž al-dīn).

2. Protection of life ((hifẓ al-nafs).

3. Protection of mind ((hifẓ al-`aql),

4. Protection of offspring ((hifz al-nasl) and

5. Protection of wealth (hịiẓ al-māl). 
Now let us attempt to justify premarital genetic testing in light of the above five Objectives of Islamic Law:

Firstly, insofar as preservation of the Faith is concerned, the Faith of the prospective marriage couples who have undergone premarital genetic testing and have been cleared of being carriers of any genetic disease would be boosted. This would result in bringing them closer to their Creator, placing their full trust in God Almighty to be blessed with healthy children once their marriage is solemnized.

Secondly, in the context of preservation of life, that would be in the form of mandatory restraining such prospective marriage couples who have been positively tested to be carriers of specific genetic diseases from contracting their marriage. Thus, that would in essence be preserving the life of their unborn who would have been predisposed to morbidity and mortality depending on the nature of the inherited genetic diseases.

Thirdly, preservation of intellect of the prospective marriage couples would be achieved after their having undergone premarital genetic testing and found not to be carriers of genetic diseases. Their anxiety would be transformed into relief and that would augur well for their sanity to have their marriage speedily solemnized. Here it may be appropriate to point out that caring for children with genetic disorders would undoubtedly affect the parents' mental sanity.

Fourthly, preservation of progeny would apply to the directive that such prospective marriage couples who are found to be carriers of genetic diseases would not be mandated to be married to each other. Hence, this would precisely be for the sake of safeguarding their offspring from succumbing to the genetic diseases that could be transmitted to them.

Fifthly, caring for children with genetic disorders would place their parents into financial difficulties and it would therefore be prudent in the context of preservation of wealth not to sanction the marriage of such prospective marriage couples who are found to be carriers of genetic diseases.

\section{JUSTIFICATIONS FOR THE COMPROMIZING OF AUTONOMY ON THE BASIS OF AL-QAWÂ'ID AL- FIQHIYYAH (LEGAL MAXIMS)}

One of the Legal Maxims (Ebrahim, 2008:3) is akhaff al-diararayn (lesser of two evils). In the context of this paper, the two evils are (i) mandatory premarital genetic testing and (ii) the prevalence of children born with genetic disorders. It would therefore be a lesser evil to compromise autonomy for the sake of a pressing social need, i.e. to prevent the birth of children susceptible to inheriting genetic disorders.

Another principle of Islamic Jurisprudence is sadd al-dharā' $\overline{1}$ which implies blocking the means to an expected end (evil) which is likely to materialize if the end towards it is not obstructed. In other words, therefore, it would be permissible to block autonomy in the context of premarital genetic testing to the expected end of safeguarding the progeny from inheriting genetic disorders.

\section{Genetic Counselling}

Genetic counselling for the prospective marriage couples who are at risk of passing the genetic disorder to their unborn offspring should be encouraged in view of the fact that such counselling conforms to the following Hadith (Prophetic Tradition): "Al-Dīn nasīhah" ("Religion is sincere advice") (Al-Naysaburi, ND, 1:238). They should be advised on making use of contraception and if they wish to have children. Moreover, it is important for them to be made aware that, in light of Islamic Medical Jurisprudence, it would be unacceptable for them to resort to: (i) sterilization, (ii) solicit third party intervention in the form of artificial insemination with donor sperm, (egg donation and surrogate motherhood and adoption) (Albar, 2002) and (iii) to legally adopt children. Nevertheless, they could foster parent a child, but that would entail observance of the rules of 'awrah (privacy) within their homes. In other words, when the female, who is foster-parented, attains puberty, she would not be able to come out in the presence of her foster father without observing the rules of seclusion of her privacy. In the same way, the foster mother will have to observe the rules of seclusion in front of her foster son. Therefore, a more viable option for them would be to resort to pre-implantation diagnosis (PGD) if they so wish to have a child who would be free from hereditary disease (Haji Ahmad, 2003). 


\section{Conclusion}

In countries where certain genetic disorders are prevalent, it would be perfectly in order, for the State to impose mandatory premarital genetic testing for hereditary disease upon its populace who intend to get married for that would be in fulfilment the five objectives of Islamic Law. However, confidentiality ought to be guarded at all times. Thus, it is important that the populace receive genetic counselling both prior to and after premarital genetic testing (El-Hamzi). However, if a couple who are both carriers of a particular genetic disorder were to still wish to take the risk and be married to each other, they should not be discouraged to do so, bearing in mind the power of du'à' (supplication). They should thus be counseled about contraception and if they do still desire to have children they should be advised as to what would be acceptable within the ambit of Islamic Medical Jurisprudence vis-à-vis their right to procreate. (Al-Aqeel, and Aida, 2005).

\section{References}

1. Albar, Muhammed Ali. April - June 1998. Genetic Counselling and Genetic Issues: An Islamic Perspective. The Fountain on Life, Knowledge and Belief. Available from:

2. http://www.fountainmagazine.com/Issue/ detail/Genetic-Counselling-and-GeneticDisseases- An-Islamic-Perspective.

3. Albar, Mohammed A. Ethical considerations in the prevention and management of genetic disorders with special emphasis on religious considerations. Saudi Med. J 2002; Vol. 23 (6).

4. Al-Arrayed, S.S. Review of the spectrum of genetic disease in East Mediterr Health J. 1999 Nov; 5(6):1114-20.

5. Al-Aqeel and I Aida. Ethical guidelines in genetics and genomics. An Islamic perspective. Saudi Med J 2005, Vol. 26 (12).

6. Eastern Biotech and Life Sciences. 2014. Pre Marital Genetic Screening. Available from:http://www.easternbiotech. com/resource_Pre $\% 20 \mathrm{marital} \% 20$ Screening.php.
7. Farlex. The Free Dictionary. Available from: http://medical-dictionary.thefreedictionary. com/autonomy.

8. Ebrahim, Abul Fadl Mohsin. 2008. An Introduction to Islamic Medical Jurisprudence. Durban. Islamic Medical Association of South Africa.

9. Al-Ghazālī, 'Abū Hāmid Muḥmmad ibn Muhammad. 1322 AH/1904 CE. Al-Mustasfa min 'Ilm al-Ușūl. Bulāq. Al-Mațba'ah alAmīriyyah.

10. Haji Ahmad, Norhayati. Islamic Views on the Science of Procreation. Eubios Journal of Asian and International Bioethics 13 (2003), (59-60).

11. El-Hazmi, Mohsen A.F. Genetical Aspects of Research and Medical Services in Islamic Countries. Available from: https://www.researchgate.net/profile/ Mohsen El-Hazmi/publication/221917595 Genethical_Aspects_of_Research_and Medical Services in Istamic Countries/ links/0 $046352 \mathrm{~b} 0 \mathrm{a} \overline{2} \mathrm{a} 7275 \overline{\mathrm{c}} 0000000 /$ Genethical-Aspects-of-Researchand-Medical-Services-in-Is lamicCountries.pdf

12. Khan, Muhammad Muhsin. The Translation of the Meanings of Sahih al-Bukhari. 1997. The Book of Sales (Bargains). 9 Vols.

13. Al-Nasayburi, Muslim ibn al-Hajjaj.N.D. Sahih Muslim. Cairo. Dar al-Sha`b. 5 Vols.

14. Oman Hereditary Blood Disorder Association. 2015. Premarital Genetic Screening. Available from: http://www.omancares.org/en/ premaritalScreening.php.

15. Qasim, 'Abd al-Rashid. Mandatory Genetic Medical Examinations. Available from: http:// www.icna.org/mandatory-premarital-medicalexaminations/.

16. Rahman, MM et al. Premarital Health Screning - A Review and Update. JAFMC Bangladesh. Vol 10, No 1 (June) 2014, p. 105. 